\title{
The Bill Elimination on Sexual Violence: Importance for Indonesian Women
}

\author{
Ratna Herawati*, Ani Purwanti and Sekar Anggun Gading Pinilih
}

Faculty of Law, University of Diponegoro, Semarang, Indonesia

\begin{abstract}
This paper aims to find out to understand the importance of the bill in improving the quality of life of Indonesian women, as well as the vision, mission, and direction of President Joko Widodo in 2019-2024. This research was conducted by using the juridical empirical method, by looking at problems in the community, then looks for the legal basis and expert opinion, and is processed using the triangulation method. The results showed that increasing cases regarding various types of violence against women in various places cause the government needs to make a regulation needed to eliminate sexual violence through the bill. Hence, the Bill on the Elimination of Sexual Violence is urgently needed in Indonesia. The findings also noted that previous regulations have not sufficiently regulated the form of protection for women against sexual violence. The main conclusion of the study is that the bill is a form of the government's responsibility to ensure the fulfillment of these rights: the right to handle, right to protection, and right to recovery.
\end{abstract}

Keywords: Indonesian, women's right, sexual violence, Elimination of Sexual Violence.

\section{INTRODUCTION}

The United Nations Declaration on Human Rights in 1948 emphasized that "everyone is born with the right to equal freedom and dignity". This affirmation is a symbol of community life with a vision of the need to respect the humanity of each person regardless of race, colour, religious and political beliefs, language, and gender. The world community recognizes that women have the right to enjoy and obtain the protection of human rights, in the political, economic, social, cultural, civil, and other fields (Suadi, 2018). This recognition was manifested in the 1967 Declaration on the Elimination of Discrimination Against Women, the 1979 Convention on the Elimination of All Forms of Discrimination Against Women which was declared in force in 1981, and the 1993 Declaration on the Elimination of Violence against Women. Gender is constructed and constructed in such a way through customs, traditions, parenting habits, education, to distinguish between the duties and social roles of men and women. Women and men are distinguished between sex (sex) biologically and the reality of sociocultural construction. In social terms, women are constructed as child caregivers, regulating households, which are related to functions in the domestic sphere, while men are as household heads, family breadwinners, serving in the public sphere (Pratama et al., 2018; Wisnaeni \& Herawati, 2020; Tyesta et al., 2020).

*Address correspondence to this author at the Faculty of Law, Universitas Diponegoro, Semarang, Jl. Prof. Soedarto, Tembalang, Semarang, Central Java 50275, Indonesia; E-mail: ratnaherawati.undip@yahoo.com
Gender-based discrimination comes from various human rights violations. Discrimination can be in the form of marginalization, which often occurs in the economic field, sub-ordination (nomenclature), the notion that women are weak, stereotypes (bad images), bad views on women, violence, namely physical and psychological attacks, excessive workload, which is the duty and responsibility of women who are heavy and continuous. Violence against women in Indonesia is divided into several types violence including the results of the 2018 National Commission on Violence against Women. The most form of violence is physical (41\%), and sexual as much $(31 \%)$. Sexual violence is the second most reported and shows that homes and personal relationships have not become safe places for women. The high number of cases of violence against women is motivated by several factors including the increase in the types of violence against women in addition to Domestic Violence (KDRT), namely sexual violence. This can be seen from the documentation of Komnas Perempuan(2013) on cases of violence against women throughout 1998-2013 showing that cases of sexual violence amounted to almost a quarter of all cases of violence or 93,960 cases of all reported cases of violence against women $(400,939)$.

The issue of access to victims of human rights violations against the National Commission on Violence Against Women is still not maximal and far from expectations. This is especially true if the victims live and are in their area, including the marginal groups such as women from poor families, women in conflictprone areas, and others. The existence of Komnas Perempuan (2014) which only exists in Jakarta 
certainly makes access difficult, so it is not effective in reaching cases of human rights violations against women in the area. Even though those in this area are often victims of violence and are very vulnerable because they are often unpublished (Patra, 2009). Efforts to resolve cases of sexual violence have actually been contained in several positive laws and regulations in Indonesia today but the formula does not regulate specifically the types and forms of sexual violence so that in the implementation of the legal form and yet the lawmakers accommodate complaints originating from the community. The government's efforts to provide legal protection for victims of sexual violence have been contained in Article 5 of Act Number 23 of 2004 concerning the Elimination of Domestic Violence stating that "shall nobody is allowed to commit marital violence in his/her household through means such as 1) physical violence; 2) psychological violence; 3) sexual violence, or 4) marital abandonment".

The situation of inequality, asymmetry, and subordination towards women appears in social, political, economic, and even more so in culture, especially when violence is committed in marital ties so that women do not report it to the authorities. This is because the patriarchal culture is still strong in Indonesia so that it has an impact on policymaking. Patriarchy provides the framing of gender inequality and concomitant unequal power, social values, entitlements, and roles (Sikweyiya et al., 2020). The other hand, in the vision, mission, and direction of President JokoWidodo for 2019-2024, to realize Indonesia as an adaptive, productive, innovative, and competitive country, it is necessary to improve Human Resources (HR) by improving the quality of life of Indonesian people, including women. The role of the government is very large to improve the quality of life of Indonesian women. Therefore, the form and type of sexual violence are not regulated in detail so that a specific formula is needed that can accommodate the forms and types of sexual violence through the existence of the Bill of Elimination of Sexual Violence.

\section{RESEARCH OBJECTIVES}

This research focuses on the importance of The Bill of Elimination of Sexual Violence for Indonesian women. This research is different from Duramy (2014) which examines sexual violence in Haiti but does not provide a solution from policymakers to deal with this gender-based sexual violence. Also, research from Jilly Ryan et al., (2018) also describes various laws in
South Africa to deal with gender-based violence, but the scope is only in the family. This research does not look deeply at the relationship between violence, quality of life, and psychological pressure for women (Hisasue et al., 2020), but provides a solution so that the quality of life of women increases so that the psychological pressure that comes from sexual violence against women is reduced.

Based on the background, the researchers are interested in writing about the importance of the bill on the elimination of sexual violence so that the following issues are identified: 1) What is the importance of the bill on the elimination of sexual violence? And 2) What is the Legal Provisions for the Eradication of Sexual Violence and Protection of Victims through the Bill on the Elimination of Sexual Violence?

\section{RESEARCH METHOD}

This research was conducted by using the juridical empirical method, by looking at problems in the community, then analyzing for the legal basis and expert opinion, and is processed using the triangulation method. In short, the normative juridical approach refers to legal research regarding the enactment or implementation of normative legal provisions in any particular legal event that occurs in society. Empirical juridical research is a type of sociological legal research. Hence, the regulation that is used as the object of the juridical method is the Bill of Elimination of Sexual Violence for Indonesian women.

Moreover, expert opinions, according to European Centre for Disease Prevention and Control (2017), refer to "scientific views or comments by a group of designated experts based on a review of scientific evidence and/or the expert opinion". In short, expert opinions are judgments about a particular issue given by an expert. Triangulation, according to Patton (1999), is an attempt in qualitative research to develop a comprehensive understanding of phenomena using several methods or data sources. This technique attempts to validate data by cross-verification from two or more sources. Triangulation is a method of synthesizing data on the correctness of research sources by using other data collection methods or various triangulation approaches. This research assessing between facts about the issue of access to victims of human rights violations of women which is still not maximal and far from expectations in Indonesia. The main objects of laws in this study are focused on the provisions regulated in the Criminal 
Code, the Law No. 23/2004 on Marital Violence and the Law No 35/2014 on Child Protection as well as improvement for women protection stipulated in the Bill of Elimination of Sexual Violence for Indonesia women.

\section{LITERATURE REVIEW}

Sexual violence is an act of degrading, insulting, attacking, and/or other acts against the body, one's sexual desires, and/or reproductive functions, by force, contrary to one's will, which causes a person to be unable to give consent in a free state, because inequality of power relations and/or gender relations, which results in or can result in physical, psychological, sexual suffering or misery, the economic, social, cultural and/or political disadvantages of the Elimination of Sexual Violence are all efforts to prevent sexual violence from occurring, dealing with, protect and restore victims, take action against the perpetrators and strive to avoid the occurrence of sexual violence. Also, sexual violence does not only occur at home and workplace. Sexual violence is defined as any sexual act, attempt to obtain a sexual act, unwanted sexual comments or advances, or act to traffic, or otherwise directed, against a person's sexuality using coercion, by any person regardless of their relationship to the victim, in any setting, including but not limited to home and work (Hartmann-Tews et al., 2020). Sa'bah (1997) noted that the issue of human sexuality was not as simple as imagined, or not as understood by most people. The discussion of sexuality has been castrated in matters of lust and descent. As if there are only two categories of human sexuality, namely a) moral sexuality, as healthy and good sexuality, b) immoral sexuality, as sick and evil sexuality".

Even though that opinion reminds us that does not narrow the discussion about sex, but the expert acknowledges one form of sexuality that is immoral and evil. This means that there is a practice of sex that can harm other parties and the community because the practice is contradictory in terms of religious practices (Abdul \&Irfan, 2001) Legal reform is realized as a whole, which includes: arrangements for preventing sexual violence; forms of sexual violence; victims' rights, including recovery; procedural law for criminal justice for sexual violence, including about verification; monitoring the elimination of sexual violence; and punishment. Also, the most important thing is that the abolition of sexual violence is capable of forming a new system that protects women from the law enforcement side and encourages the role of the state to be more responsible for efforts to recover victims and prevent sexual violence in the future. The proposed Bill on the Elimination of Sexual Violence is an attempt to reform the legal system to deal with systemic sexual violence against women. The Bill on the Elimination of Sexual Violence can be used to accommodate the needs and interests of women victims of violence because this bill is based on a study of experiences and how they face the legal process. The Bill on the Elimination of Sexual Violence (hereinafter abbreviated as the Bill on the Elimination of Sexual Violence) is an effort to reform the law to overcome these various problems. This bill has various objectives to 1) prevent the occurrence of sexual violence incidents; 2) develop and implement mechanisms for handling, protection, and recovery that involve victims of victims so that victims can surpass the violence they experience and become survivors; 3 ) provide justice for victims of sexual crimes, through criminal acts and strict actions for perpetrators of sexual violence; 4) guaranteeing the implementation of state obligations, family roles, community participation, and corporate responsibility in creating a sexual violence-free environment. The government has established an independent body that is tasked with the advancement and protection of women's rights and combating violence against women called the National Commission of Anti Violence against Women (KomnasPerempuan). According to a report from the Commission, there are 15 kinds of violence against women that have been identified.

First, rape is an attack in the form of forced sexual relations by using a penis towards the victim's vagina, anus, or mouth, can also use fingers or other objects. Attacks are carried out by violence, threats of violence, detention, psychological distress, abuse of power, or by taking advantage of a forced environment. Second, sexual intimidation, including threats of rape experiments, is sexual violence in the form of actions that attack sexuality for women who are involved in psychological suffering for women victims (Stanko, 2013). Sexual intimidation can be delivered directly or indirectly through mail, SMS, e-mail, and others. Threats or trials of rape are also part of sexual intimidation.

Third, sexual harassment, namely sexual acts through physical or non-physical touch with the target of sexual organs or victim's sexuality. It includes using whistles, flirting, I, showing pornographic material and sexual desires, pokes or touches on parts of the body, movements or gestures that are sexual resulting in discomfort, feeling offended, and possibly causing 
health problems and safety. Fourth, sexual exploitation, which is an act of abuse of power which is not good, trustworthy, to satisfy sexuality, and for gaining profits in the form of money, social, political, and others. Fifth, trafficking of women for sexual purposes is the act of recruiting, transporting, accommodating, sending, transferring, or receiving someone with the threat of violence, use of violence, abduction, confinement, forgery, fraud, abuse of power or vulnerable positions, debt bondage or payment or benefits towards victims directly or other people who control them, for prostitution or other sexual exploitation. Trafficking in women can occur within countries and between countries (David, (2008).

Sixth, forced prostitution is a situation where women experience deception, threats, or violence to become sex workers (Serughetti, 2018). This situation can occur during the recruitment period as well as to make the woman powerless to release herself from prostitution, for example by confinement, bondage, or threats of violence. Forced prostitution has several similarities, but it is not always the same as sexual slavery or trafficking for sexual purposes. Seventh, sexual slavery is a situation where the offender feels that he is the "owner" of the victim's body so that he has the right to do anything including obtaining sexual satisfaction through rape or other forms of sexual violence. This slavery includes household situations or other forms of forced labour, as well as sexual intercourse with their confinement. Eighth, forced marriage, including divorce is a type of sexual violence because of the Forced relationship between people who are not separated from the marriage that the woman does not want (Martin, 2017). Ninth, forced pregnancy, namely the situation when a woman is forced, with violence or the threat of violence, to continue the pregnancy she does not want. This condition, for example, is experienced by women who are rape victims who are not given other options except to continue their pregnancy. Also, when the husband is using contraception so that the woman cannot adjust the distance of her pregnancy. This pregnancy coercion differs from a forced pregnancy in the context of crimes against humanity in the Rome Statute, namely the situation of unlawfully restricting a woman to become pregnant by force, makes the ethnic composition of a population or for violating other international laws (Grey, 2017).

Tenth, forced abortion is abortion that is carried out because of pressure, threats, or coercion from other parties. Forced contraception and sterilization, namely the installation of contraceptives and/or the implementation of sterilization without the full consent of the woman because she is not fully informed or deemed incompetent to give consent (Patel, 2017). Other abuses include sexual torture which is a special action that attacks female organs and sexuality, which is done intentionally, causing intense pain, suffering, physical, spiritual, and sexual. This is done to obtain recognition or information from him or a third person or to punish him for an act that has been or has been allegedly committed by him or a third person. Sexual torture can also be done to threaten or force him, or a third person, based on discrimination for any reason. This includes forms if the pain and suffering are caused by incitement, approval, or the knowledge of public officials or law enforcement officials. Inhuman and sexual nuances of punishment are punishments that cause suffering, pain, fear, or extraordinary shame that cannot be included in torture. It includes caning and punishment - punishments that are humiliating or to demean humans because they are accused of violating moral norms. The practice of sexual nuances that endanger or discriminate against women, namely sexual habits that are sexual and can cause physical, psychological, and sexual injury to women. This habit can also be done to control female sexuality in a perspective that denigrates women (Brandt \& Rudden, 2020). Female circumcision is one example. Sexual control, including discriminatory rules based on morality and religion, namely violence and threats of violence directly or indirectly to threaten or force women to internalize certain symbols that they do not approve of.

Sexual violence has been spreading like an epidemic in society, but not many people understand and are sensitive about this problem. Sexual violence is often seen as a mere crime of decency, even though the facts show that the impact of sexual violence on victims is very serious and traumatic and may last a lifetime. Even in some cases, sexual violence can encourage victims to commit suicide (Smiler\& Epstein, 2010). This Draft Law on the Elimination of Sexual Violence (hereinafter abbreviated as the Draft Law on the Elimination of Sexual Violence) is an attempt to reform various issues of violence against women and children. The view that sexual violence is a crime against morality is even supported by the state through the contents of the Criminal Code (KUHP). In the Criminal Code, sexual violence such as rape is considered a violation of the norms of decency. This categorization not only reduces the degree of crime committed but also creates the view that sexual 
violence is a matter of mere morality. This further affects many cases of sexual violence that are not handled legally, but through peace efforts outside the judicial process, whereas, the experience of women victims of sexual violence shows that sexual violence can destroy the entire integrity of the victim's life which causes the victim to feel unable to continue her life (Sullivana\& Olsen, 2016). It must threaten the sustainability of the nation and the quality of future generations. The distinctive aspect of sexual violence which is always associated with morality discourse is also one of the biggest obstacles in the efforts of victims to obtain their rights to truth, justice, recovery, the fulfillment of a sense of justice, and a guarantee of non-recurrence of events. The Bill on Sexual Violence seeks to resolve various cases of existing sexual violence by identifying several forms and types.

\section{RESULTS AND DISCUSSION}

In general, legal protection is interpreted as a law/regulation that applies in Indonesia and provides protection for women, especially from acts of violence, exploitation, and discrimination in various aspects of life, social, cultural, economic, educational, civil, and political. The formation and existence of law cannot be separated from the goal of getting the best solution in handling a conflict. In a modern country like now, the law is an option, but it is not easy to achieve its objectives. According to Hartono (2002), the law is not only written regulations but instead lies on a hierarchical system with an arrangement such as legislation; jurisprudences; conventions/customary laws; international agreements or treaties; regulations issued by international institutions; processes and procedures; legal education; law actors and legal facilities and infrastructure. Sexual violence occurs repeatedly and continuously, but not many people understand and are sensitive about this problem. Sexual violence is often seen as a mere crime of decency, even though the facts show that the impact of sexual violence on victims is very serious and traumatic and may last a lifetime. Even in some cases, sexual violence can encourage victims to commit suicide (Smiler\& Epstein, 2010). This draft Law on the Elimination of Sexual Violence (hereinafter abbreviated as the Draft Law on the Elimination of Sexual Violence) is an attempt to reform various issues of violence against women and children. The view that sexual violence is a crime against morality is even supported by the state through the contents of the Criminal Code (KUHP). In the Criminal Code, sexual violence such as rape is considered a violation of the norms of decency. This categorization not only reduces the degree of crime committed but also creates the view that sexual violence is a matter of mere morality. This in turn affects many cases of sexual violence that are not handled legally but through peace efforts outside the judicial process.

The Draft Law on Sexual Violence seeks to resolve various cases of existing sexual violence by identifying several forms and types (Wariyatun, 2019). The article presented in the Draft Sexual Violence Bill which has not been regulated in other laws includes the implementation of the investigation of sexual violence contained in Article 5 of the Draft Sexual Violence Bill as follows in Article 5 that: (1) State institutions, the Government, Regional Governments must conduct violence prevention sexual. (2) Prevention of sexual violence as referred to in paragraph (1) includes but is not limited to: a. education; b. infrastructure, public services, and spatial planning; c. governance and institutional governance; d. economy; and e. social and cultural (3) Prevention of sexual violence as intended by taking into account conflict situations, natural disasters, the geographical location of the region, and other special situations. (4) Prevention of sexual violence as referred to in paragraph (2) letters a through $e$ is coordinated by the ministry in charge of women's empowerment and child protection affairs. (5) The National Commission on Violence Against Women and the Indonesian Child Protection Commission prepares material and guidelines for implementing prevention of sexual violence as referred to in paragraph (2)

Moreover, the Bill also accommodates the victim's rights as a part of restorative justice whereby the policy of anti-sexual violence should also include the recovery process of the victims to be reintegrated back to their normal social life. The victims' rights encompass three kinds of rights; the right to handling, the right to protection, and the right to recovery. The fulfillment and enjoyment of these rights are the obligations for the state in accordance with the victims' needs and conditions. This is important to prevent possible retaliation and further cyclical repetition of sexual violence to the victims. The state obligations to guarantee the fulfillment of these rights include actions such as 1) establishing national and regional policies as to the fulfillment of the victim rights and also its further protection to the family, the policy of which 
should be integrated into the internal management policies of the related state institutions such as law enforcement and victim protection program; 2) allocating state funds into the policies which must be authorized into the state budget, and; 3 ) strengthening the roles and responsibilities of the family, community, society, and corporations as to the implementation of victims' rights fulfillment.

The right for handling encompasses sub-criteria which constituted the right as a whole and thus, the responsibilities of the state to fulfill such as the right to information regarding the whole process and outcome of the case's handling by the law enforcement; the right to retrieve documents; the right to legal assistance/aid; the right to psychological therapy; the right to healthcare; the right to other services and facilities which are deemed important for the victim's needs, and; the right to unbiased visum et repertum and accommodative treatment during the psychiatric check. Furthermore, the right to protection encompass these services which are provided for access to information regarding the establishment of protection services and facilities which the victim will be getting; provision for information as to the rights and protection facilities; protection from any threat or act of retaliation from the perpetrator or its associates and also the possibility of repeating offenses, i.e. restraining order; protection of identity secrecy; protection from demeaning or degrading acts/stigma by law enforcement officials against the victims; protection from forced suspension or redeployment of job, education, and/or political access; and immunity for victim/witness from countercharges, civil or criminal, regarding the case of sexual violence which the victim/witness reported.

Moreover, the right to recovery includes physical recovery; psychological recovery; economic recovery; social and cultural reintegration, and; restitution. The recovery process before, during, and after the trial/settlement process includes the provision of health services for physical recovery; psychological reinforcement for victims regularly; providing information about victims' rights and judicial processes; providing information about recovery services for victims; legal assistance; providing transportation assistance, living expenses or other necessary expenses; providing a decent and safe place to live; providing spiritual and spiritual guidance for victims and their families; provision of educational facilities for victims or child victims; providing population documents and other supporting documents needed by victims; implementation of psychological reinforcement to the families of victims and/or the closest communities of victims; and strengthening community support for the recovery of victims.

\section{CONCLUSION}

The results showed that increasing cases regarding various types of violence against women in various places cause the government needs to make a regulation needed to eliminate sexual violence through the bill. Hence, the Bill on the Elimination of Sexual Violence is urgently needed in Indonesia. The findings also noted that previous regulations have not sufficiently regulated the form of protection for women against sexual violence. The main conclusion of the study is that the bill is a form of the government's responsibility to ensure the fulfillment of these rights: the right to handle, right to protection, and right to recovery.

The results also showed that considering the exhaustive services for the victim (and witness) of sexual violence offense, the Sexual Violence Bill is expected to be a regulation that overcome the problems of sexual violence cases that occur in women and children in Indonesia so that the cases can be handled properly, because in the Sexual Violence Bill through law enforcement mechanisms will provide justice for victims of sexual crimes, through criminal and strict actions for perpetrators of sexual violence. The Bill on Sexual Violence will guarantee the implementation of state obligations, the role of the family, community participation, and corporate responsibility in creating a sexual violence-free environment. Encouraging the Indonesian Government to immediately ratify the Sexual Violence Bill as an effort to resolve the problem of sexual violence and minimize victims of sexual violence in Indonesia. As long as the Draft Sexual Violence Bill has not yet been passed, law enforcement through existing regulations will still be unable to accommodate and guarantee the law enforcement of various cases of sexual violence that occur in female and child victims.

\section{SUGGESTIONS}

The results indicate that human rights violation still happens in any legal subjects including women and children. The matter of which regarding sexual violence has been escalating in recent years. The results emphasized that the government's handling of violence against women and children, which is regulated in the 
Criminal Code, the Law No. 23/2004 on Marital Violence and the Law No 35/2014 on Child Protection, is unable, to some extent, to prevent and reduce sexual violence cases which have been multiplying in terms of the kind of violent practice is used. Within the new Bill proposed, the regulation scope is including prevention, treatment, victim protection and recovery, and the handling of perpetrators.

The results indicate that the intention to eradicate sexual violence within the Bill needs collaboration of the state's duty in enforcing the law and citizens' participation regarding public awareness on violence against women and children. Therefore, practically, although creating equality between men and women is not an easy problem to solve, the available law is the right basis for realizing protection for women victims of gender-based violence. It is also suggested the endeavour of the government to provide protection more improvements of equality for women, so the realization requires cooperation in networks. When the government commits to protects women victims of violence, it is our shared responsibility to strive for prevention, protection, prevention of women victims of violence to obtain their rights as stipulated in the law while paying attention to aspects that influence in society.

\section{REFERENCES}

Abdul, W., \& Irfan, M. (2001). Protection of victims of sexual violence. Advocacy for Human Rights. Bandung: Refika Aditama.

Brandt, S., \& Rudden, M. (2020). A psychoanalytic perspective on victims of domestic violence and coercive control. International Journal of Applied Psychoanalytic Studies, 17(3), 215-231. https://doi.org/10.1002/aps.1671

David, F. (2008). Trafficking of women for sexual purposes. Canberra: Australian Institute of Criminology.

Duramy, B. F. (2014). Gender and violence in Haiti: women's path from victims to agents. Rutgers University Press. https://doi.org/10.36019/9780813563169

European Centre for Disease Prevention and Control. (2017). Expert opinions. Retrieved from https://www.ecdc.europa.eu/en/ infectious-diseases-public-health/scientific-advice/expertopinions

Grey, R. (2017). The ICC's first 'forced pregnancy'case in historical perspective. Journal of International Criminal Justice, 15(5), 905-930. https://doi.org/10.1093/jicj/mqx051

Hartmann-Tews, I., Bartsch, F., Wagner, I., \& Rulofs, B. (2020). Managing prevention of sexual violence and the role of commissioners in national sport federations in Germany. Sport Management Review, 23(1), 155-169. https://doi.org/10.1016/i.smr.2019.09.006

Hartono, S. (2002). The Impact of Terrorism on Transnational Law. Paper presented at the General Lecture, Jakarta: Faculty of Law, Krisnadwipayana University.

Hisasue, T., Kruse, M., Raitanen, J., Paavilainen, E., \& Rissanen, P. (2020). Quality of life, psychological distress and violence among women in close relationships: a population-based study in Finland. BMC women's health, 20, 1-10. https://doi.org/10.1186/s12905-020-00950-6

KomnasPerempuan. (2013). Fact Sheet 15 Types of Sexual Assault. Jakarta: KomnasPerempuan. Retrieved August 20, 2004, from http://www.komnas perempuan.go.id/wpcontent/uploads/2013/12kekerasan-seksual-kenali-dantangani.pdf

KomnasPerempuan. (2014).Intimidation and Threats of Sexual Violence in Cases of Religious Intolerance in the KomnasPerempuan Special Rapporteur's Report on Violence and Discrimination in the Context of Violation of Constitutional Rights

Martin, L. V. (2017). Restraining forced marriage. Nev. LJ, 18, 919. https://doi.org/10.2139/ssrn.2962589

Patel, P. (2017). Forced sterilization of women as discrimination. Public health reviews, 38(1), 1-12. https://doi.org/10.1186/s40985-017-0060-9

Patra, R. (2009). Efektifitas kelembagaan komnas perempuan dalam perlindungan HAM bagi Perempuan di Indonesia. MasalahMasalah Hukum, 41(4), 596-605.

Patton, M. Q. (1999). Enhancing the quality and credibility of qualitative analysis. Health services research, $34(5 \mathrm{Pt} 2)$ 1189.

Pratama, G.P., Purwanti, A., \&Wijaningsih, D. (2018). Yogyakarta Special Region Policy Upon Gender Biased Leader Transition Reviewed from Law no. 13/2012 on the Special Rights of Yogyakarta Special Region. IOP Conference Series: Earth and Environmental Science 175(1),012196 https://doi.org/10.1088/1755-1315/175/1/012196

Ryan, J., Esau, M. V., \& Roman, N. V. (2018). Legislative response to family violence in South Africa: A family centered perspective. Aggression and violent behavior, 42, 1-8. https://doi.org/10.1016/j.avb.2018.06.009

Saabah,M.U. (1997).Sex \& Us. Jakarta: Gemalnsani Press.

Serughetti, G. (2018). Rethinking force and consent, victimisation and agency: a feminist approach to prostitution policy. Femeris: Revista Multidisciplinar de Estudios de Género, 3(2), 79-107. https://doi.org/10.20318/femeris.2018.4321

Sikweyiya, Y., Addo-Lartey, A. A., Alangea, D. O., Dako-Gyeke, P., Chirwa, E. D., Coker-Appiah, D., ... \& Jewkes, R. (2020). Patriarchy and gender-inequitable attitudes as drivers of intimate partner violence against women in the central region of Ghana. BMC public health, 20, 1-11. https://doi.org/10.1186/s12889-020-08825-z

Smiler, A. P., \& Epstein, M. (2010). Measuring gender: Options and issues. In Handbook of gender research in psychology (pp. 133-157). Springer, New York, NY https://doi.org/10.1007/978-1-4419-1465-1 7

Stanko, E. (2013). Intimate Intrusions (Routledge Revivals): Women's Experience of Male Violence. Routledge. https://doi.org/10.4324/9780203521014

Suadi, A. (2018). Peranan Peradilan Agama Dalam Melindungi Hak Perempuan Dan Anak Melalui Putusan Yang Memihak Dan Dapat Dilaksanakan/The Role Of Religious Court In Women And Children Rights Protection Through Partial And Executable Decision. Jurnal Hukum dan Peradilan, 7(3), 353374. https://doi.org/10.25216/JHP.7.3.2018.353-374

Sullivan, C. M., \& Olsen, L. (2016). Common ground, complementary approaches: adapting the Housing First model for domestic violence survivors. Housing and Society, 43(3), 182-194. https://doi.org/10.1080/08882746.2017.1323305

Tyesta, A.L.W., Saraswati, R., \& Arif, F. (2020). Implications of legal positivism of the promotion of children's rights on national law. Journal of Advanced Research in Law and Economics 11(2), 661-666.

https://doi.org/10.14505/jarle.v11.2(48).36 
Wariyatun, W. (2019). Creating zero tolerance for violence against women. Asian Journal of Women's Studies, 25(3), 459-467. https://doi.org/10.1080/12259276.2019.1638047

Wisnaeni, F., \& Herawati, R. (2020). The Politics of Law of Pancasila-based Democracy in Indonesia as the World's
Third Largest Democracy. Academic Journal of Interdisciplinary Studies, 9(4), 39-39.

https://doi.org/10.36941/ajis-2020-0059

Received on 15-01-2021

Accepted on 16-02-2021

Published on 18-03-2021

https://doi.org/10.6000/1929-4409.2021.10.81

(C) 2021 Herawati et al.; Licensee Lifescience Global.

This is an open access article licensed under the terms of the Creative Commons Attribution Non-Commercial License (http://creativecommons.org/licenses/by-nc/3.0/) which permits unrestricted, non-commercial use, distribution and reproduction in any medium, provided the work is properly cited. 